\title{
Proteasome Subunit Beta Type-8
}

National Cancer Institute

\section{Source}

National Cancer Institute. Proteasome Subunit Beta Type-8. NCI Thesaurus. Code C112077.

Proteasome subunit beta type-8 $(276 \mathrm{aa}, \sim 30 \mathrm{kDa})$ is encoded by the human PSMB8 gene. This protein plays a role in both protein metabolism and the generation of MHC class I-binding peptides. 